\title{
Management of Amnesty Programme for Sustainable Livelihood in the Niger-Delta Region of Nigeria: Challenges and Policy Action
}

\author{
Dr. Samuel Okurebia, Dr. Ekong Daniel \\ Department of Business Management Faculty of Social and Management Sciences Akwa Ibom State University \\ P. M. B. 1167, Uyo Akwa Ibom State Nigeria \\ Faculty of Social and Management Sciences Akwa Ibom State University P. M. B. 1167, Uyo Akwa Ibom State \\ Nigeria
}

\begin{abstract}
Many years of deprivation, marginalization and cheating of the Niger Delta Region of Nigeria led to the youth in attempt to find solution to the neglect formed themselves into groups which became aggressive as a result of the use of arms in approach and operation that brought about a near chaos environment in the region. As a response to curb the deplorable security situation in the region, the federal government of Nigeria initiated and pronounced the Niger Delta Amnesty Programme (NDAP). This study attempted to assess the success of the amnesty programme to deliver a sustainable livelihood for the repentant ex-militants and restore peace and security in the region. The study employed questionnaire and interview methods randomly administered in three of the nine states of the region. The study observed reoccurrence of crime, high consumption of illicit drugs, threat to local government council executives and intra/inter cult conflicts among others in the region. Its recommendations included decentralization of the amnesty rehabilitation camps and adoption of definite goals for the amnesty programe in order to achieve sustainable peace and livelihood in the region.
\end{abstract}

Keywords: Amnesty, Sustainable Livelihood, Sustainable Development, Niger Delta, Nigeria

\section{Introduction}

Competition for control of vast natural resources especially the petroleum resource available in the Niger Delta of Nigeria has been one of the single biggest drive for conflict since Nigeria's post independence history. In 1967 for instance, in an effort to halt the perceived theft of the oil wealth by foreigners from outside the Niger Delta, the South-Eastern Region attempted to secede from the country to declaring an independent state of the Republic of Biafra. It is not surprising to observed that, popular resentment in the Niger Delta in recent years continue to aggravate, giving rise to a number of political movements, militant organizations and criminal gangs, fighting for "resources control". These groups have continued to fight, using all kings of tactics in order to get their share of the Niger Delta wealth and also to put pressure on the government for their legitimate control of oil and gas. Oil theft (bunkering), kidnapping and hostage taking, riots, protests, and attacks on oil companies and their foreign operators, have therefore become a daily incidence in the region which now attract national and international attention (Awoniyi 2009).

Before the disarmament exercise, the militants have succeeded in reducing Nigerian's oil output by more than half (Ebo, 2005). The sharp drop in the nation's daily crude oil output from 2.6 million barrel per day (bpd) to 500,000 bpd, coupled with the dwindled oil price at the world oil market, resulted in a massive loss of revenue for the federal government (Emmanuel, 2005). It therefore became imperative for the Nigerian government to find a lasting solution to the Niger-Delta militancy problem. It was for this reason that on $25^{\text {th }}$ June, 2009, the late President Umaru Musa Yar'adua, in a nation-wide broadcast declared amnesty for all militants, especially those in the Niger Delta Region who were engaging in all forms of criminal practices including pipeline vandalisation, illegal arm proliferation. The government amnesty package, worth about N50 billion included payment of monthly allowance to repentant militants, training and empowerment of all repented militants who were willing to surrender their arms (Odile, 2008; Nwanko \& Ifeadi, 1998, and Ukiwo, 2008).

While the amnesty was generally applauded by both local and international agencies and organizations, many militants exhibited initial resistance to key in to the offer. They doubted the genuiness of the federal government sincerity, considering the reprisal by the military against a militant king pin in Delta State, as a result of the brutal killing of several solders by members of the militant group. This and other factors such as, failure of several peace moves made to pacify the militants from attacking government officials and staff of major oil companies constituted major barriers at the commencement of the implementation of the first phase of the amnesty programmes. These initial fears gradually eroded as Federal Government went further to put up measures aimed at ensuring its commencement. Among such practical steps was the inauguration of the 
Presidential Amnesty Committee (PAC) to see to the implementation of the Amnesty Programmes (Ayaero, 2009).

Interestingly, the October 4, 2009 deadline given to all militants to handover their weapons in return for government amnesty recorded a remarkable success even amidst infringes and rivalries from diverse quarters as the ranks and file of all militant groups accepted the amnesty offer while government had resolved to put in place incentives and facilities that will help to rehabilitate the majority of youths who took up arms to agitation for a better Niger Delta. The federal government announced that approximately, 15,000 militants accepted the amnesty offer. Later the number increased to over 20,000 (Adebayo, 2010). According to the amnesty plan, those who surrendered their arms were to be enrolled in rehabilitation programme and be given a stipend of Sixty Five Thousand naira (N65,000.00) per month (Reuters, 2009). Nearly all the notorious militant groups, including the Movement for the Emancipation of the Niger Delta (MEND) accepted the amnesty programme (Strouse, 2009).

Regrettably, despite the lofty goals of the programme, it has been observed that, post amnesty Nigeria is still witnessing problems of militant activities such as, illegal arm proliferation, killing, kidnapping, armed robbery, unemployment and general urban crimes, despite governments efforts to solve these problems. Unfortunately, there was little field based information regarding what PAC seeks to offer and achieve in definite terms to overcome the recurring challenges to the successful militant recuperation and integration. This study was therefore initiated to fill the knowledge gap. The study sought answers to the following questions to determine solution to the militant problems and sustainable peace in the Niger Delta:

1. What is the rationale for declaring the amnesty programmes?

2. What does the Presidential Amnesty Committee (PAC) seeks to achieve and what is their scope?

3. What constraints have confronted PAC and how would it cope with these constraints?

Answers to these questions have much broader implications and will offer practical policy directive on how to implement a successful amnesty programmes in the country.

\section{THE STUDY LOCATION}

The study was conducted in the Niger Delta Region of Nigeria. The Niger Delta or the delta of the Niger River in Nigeria, is a densely populated region sometimes called the Oil Rivers because it was once a major producer of palm oil. The area was the British Oil Rivers Protectorate from 1885 until 1893, when it was expanded and became the Niger Coast Protectorate.

The Niger Delta, as now defined officially by the Nigerian Government, extends over about 70,000 $\mathrm{km}^{2}$ and makes up $7.5 \%$ of Nigeria's land mass. Historically and cartographically, it consists of present day Bayelsa, Delta and Rivers States. In the year 2000, however, Obansanjo's regime expanded it's definition to include Abia State, Akwa Ibom State, Cross River State, Edo State, Imo State and Ondo State (see Fig. 1). Some 20 million people of more than 40 ethnic groups, speaking some 250 dialects live in the Delta; the Ijaw being in the majority. Their livelihoods are primarily based on fishing and farming.

Coincidentally, Nigeria has become Africa's biggest producer of petroleum, including many oil wells in the Oil Rivers. Some 2 million barrels a day are extracted in the Niger Delta. Since 1975, the region has accounted for more than $75 \%$ of Nigeria's export earnings. Much of the natural gas extracted in oil wells in the Delta is immediately burned, or flared, into the air at a rate of approximately 70 million $\mathrm{m}^{3}$ per day. This is equivalent to $40 \%$ of African natural gas consumption, and forms the single largest source of greenhouse gas emissions on the planet. The environmental devastation associated with the industry and the lack of distribution of oil wealth have been the source and/or key aggravating factors of numerous environmental movements and inter-ethnic conflicts in the region (Wikipedia, 2013). 


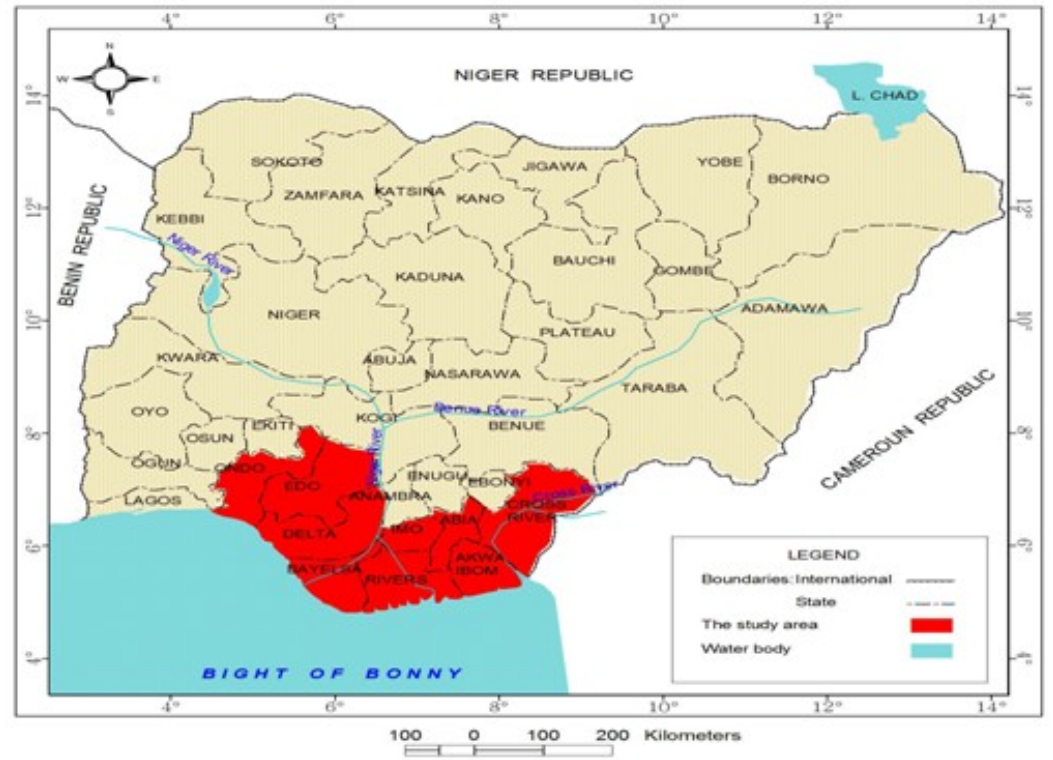

Fig . 1: The location of the Niger Delta Region on the map of Nigeria

\section{Methodology}

Out of the nine states in the Niger Delta Region, three states were sampled. They include; Akwa Ibom, Cross River, and Rivers States. Data for the study were obtained through interview and questionnaire methods which involved Amnesty implementation agencies in the three selected States of the Delta Region. Information were obtained from the Militant Rehabilitation Camp at Obubra in Obubra Local Government Area of Cross River State, the Amnesty Collection Centre at the Federal Technical and Science College, Uyo, Akwa Ibom State, the Niger Delta Freedom Fighters, - Akwa Ibom State Branch. Structured and non structured interviews were conducted with ex-militant leaders from Rivers and Bayelsa State. Also, individuals from the general public were randomly selected for interviews to have their views about the current amnesty programme of the Federal Government.

Six trained research assistants were engaged to collect data between May and August 2010. The main focus of data collection was to assess the extent to which the amnesty programme has reduced militant crimes in the region. Data were collected from eighty five (85) ex-militants, twelve (12) officials, and one hundred and sixteen (116) other persons. The field assistants helped in the distribution and retrieving copies of the questionnaire from respondents. They also assisted during interview sessions in interpreting the questions into vernacular and recorded the responses accordingly. Two were recruited from each of the states sampled.

\section{The Niger Delta Pre-Amnesty Situation}

Militant activities in the Niger Delta Region of Nigeria began as a protest against environmental damages to the fragile fishing and agricultural communities of the Niger Delta. (Edokpayi, 2009). As has been noted earlier, the region which comprises Abia, Akwa Ibom, Bayelsa, Cross River, Delta, Edo, Imo, Ondo and Rivers States is the world's largest wetland with the largest reserve of crude oil and gas in Africa. With the discovery of oil in the late 1960s the area remained largely underdeveloped with little or no effective physical infrastructures. Past political administrations have left the region environmentally degraded resulting in complex social and economic problems, deep rooted mistrust, occasioned by unemployment, armed robbery and other criminal activities. (Ibeanu, 1997; Izeze, 1999). The deterioration in relationship between the oil companies and the host communities in the area became apparent as these companies failed in their community development promises and agreement, thus, escalating the problem of the Niger Delta Region. (Naagbanton, 2007).

It is argued that, the collapsed of the security network, dwindled basic services, marginalization and exclusion of youths and women from their time-honoured traditional occupation of farming and fishing, endemic poverty and insincerity on the part of the oil companies in combination with the perceived neglect of the region by the Federal government exacerbated the Niger Delta crisis. Also, lack of political will on the part of the National Government, lack of economic goods and services, poor security situation as well as the perceived apathy, complicated the already soiled relationship between operators of the oil companies, government and the Niger Delta people. Through different media reports, deprivation, marginalization, cheating and frustration by the Federal Government and the oil companies were expressed by the people of the region. They anchored their arguments on the fact that, the region contributes over ninety percent of the nation's foreign exchange earnings, through oil exploration and exploitation. (Ibeanu, 1997). They argue also that, while the 
proceeds from oil is shared among the thirty-six (36) states and seven hundred and seventy four (774) local government areas in the country on the basis of population and national spread, non-oil producing sections of the country, with larger population figures, receive more from the federation account than the Niger Delta States which bear the burden of these exploitation (Osaghae, 2006).

The Niger Delta people also argued that, while the Federal Capital Territory (Abuja) and many states outside the Niger Delta region enjoy constant electricity supply good roads, steady water supply, and other socio-economic infrastructures, the Niger Delta region is bedeviled with darkness, epileptic power supply and near drought, while Bayelsa State for instance, is yet to be linked to the National Grid. The Niger Delta indigenes watch daily as their oil is being exploited and sold for billions of dollars daily, leaving the communities with-dug out holes, bad roads and degrading environment. (Dode, 2007). As a result of the neglect, the youths of the area, in order to find solution to the situation formed themselves into groups which later became aggressive as a result of the use of arms both in approach and in operation. The following are the immediate circumstances that resulted in governments repressive actions against the militant activities:

i) Attempts by militants to seize large quantity of stolen crude oil in Delta State under the custody of the Joint Task Force (JTF);

ii) An attack on the presidential palace in Malabo, Equatorial Guinea;

iii) Threat to attack Agip Oil Company, an Italian facility to protest the Italian Government's proposal to tackle insecurity in the region;

iv) An attempt to attack Agip terminal in Brass Local Government area of Bayelsa State;

v. Vandalizing of Agip major pipeline at Lagos camp in Brass L. G. A. of Bayelsa State;

vi. There were also reports that the militants had planned to destroy oil terminals at River, Delta and Akwa Ibom States. They targeted Bonny terminal, Sea-eagle offshore facility and Bonga Field in Bayelsa, Exxon Mobile off-shore oil facilities at Ibeno and Qua-Iboe, Okwori and Anton oil terminals in Akwa Ibom. Others were Caw Thorne channel, Southern Ijaw and Ekeremor of Rivers and Bayelsa States, respectively. Big oil tankers carrying crude oil meant for export Shell petroleum pipelines in Alakiri, and Dutch Island of Okirika, Rivers State were also at the risk of being destroyed by the militants (Charles and Dayo 2008).

On Monday, November 12, 2007, suspected militants attacked Ibeno jetty in Eket L. G. A. of Akwa Ibom State, demobilized the Naval security personnel on duty, blew up the police patrol boat, killed a pregnant woman while demanding for their own share of the oil revenue. MEND immediately claimed responsibility for the attack. Also at Ikot Ekpene Local Government Area of Akwa Ibom State, militants dressed in a military uniform attacked and kidnapped four Lebanese while on duty at a road construction cite in the area, leaving soldiers, policemen and civilians dead on the process. (Etim and Onwuka, 2006). In Rivers, Bayelsa, Edo, Abia, Cross River, Delta and other Niger Delta States, the pictures were the same. Several lives were lost, properties destroyed, and the entire region became a high security risk zone. The economy of the region dwindled remarkably as so many businesses and financial houses folded up.

\section{THE AMNESTY OFFER}

The situation highlighted in the preceding section urgently called for an emergency attention both by meaningful individuals, corporate organizations, local, state and federal governments. As a response to curb the deplorable security situation in the region and the multiplier effect on the national economy, the Federal Government under the leadership of late President Umaru Musa Yar'Adua initiated and pronounced the Niger Delta Amnesty Programme (NDAP) in addition to the creation of the Niger Delta Ministry (NDM).

Large numbers of the region's insurgents who had been sabotaging petroleum production and fighting government forces in a campaign for a greater share of oil revenues, accepted the government's offer of amnesty. Hard lined elements of the main militant group, the Movement for the Emancipation of the Niger Delta (MEND), although skeptical of the offer consented to the peace talks. On November 14, 2009, late President Yar'Adua held the first meeting with the negotiating team appointed by MEND led by Noble Laureate Prof. Wole Soyinka. The first meeting was unsuccessful. In order to consolidate the discussions at the first meeting, build confidence and prevent further distrust, the late President needed to beef up the process of returning former fighters to the society and consolidates his preliminary proposals to address the underlying economic and social problems of the area. The turnout of more than 15,000 militia men far beyond government projected figure of about 10,000 men at the second meeting was remarkable, particularly, as the number included virtually all the known militia groups under MEND across the Niger Delta States. (Awoniyi, 2009).

Before now, the scale of financial loses resulting from militant activities had made government to be more committed to the issue of amnesty. At a meeting between former President, Chief Olusegun Obasanjo, Alhaji Asari Dokubo, and Ateke (leaders of the major militant groups in the area) the Niger Delta People's Volunteer Force (NDPVF) and the Niger Delta Volunteers (NDV), five thousand weapons were handed in under a "gun-for-money", skills training and employment arrangement, 
Government made meaningful concession and constitutional advancement on resource control to demonstrate its seriousness on the amnesty deal. Constitutional advancement on $10 \%$ to be allocated for the development of core oil producing communities. Plans to rehabilitate former militants were instituted and these included education and job creation. In Rivers State alone, more than 3,000 former militants signed-up for the state-run rehabilitation programme, which provides one hundred and thirty four US dollars (US 154 dollars) per month as stipend for repentant militants, as well as funding for business start-ups, trade as well as further education to all repentant militants. By the end of year 2009 the federal government had approved $\$ 1.34$ billion to boost roads, hospitals and school rehabilitations in the Niger Delta region. The Royal Dutch Shell, one of the biggest oil companies operating in the area also began retraining of former militants (Adebayo, 2010).

The promised rehabilitation and re-integration programmes of ex-militants commenced on Monday June 28, 2010 in Obubra, Cross River State, and was expected to end by December, 2010. A delegation comprising thirty peace and conflicts experts from the Road Island in United States and Herberts Luntini Nonviolent centre in South Africa had been hired to undertake transformation and guidance two week training for the ex-militants in the respective camps. A total 20,192 ex-militants registered in the programme (Judith, 2009).

\section{Discussion Of Findings}

Basically, the Presidential Amnesty Committee (PAC) inaugurated by Late President Umaru Musa Yar'Adua was to oversee the rehabilitation, re-orientation and re-integration of all repentant militants not only in the Niger Delta, but in the entire country so that, sustainable peace and progress could be achieved in the nation. However, findings from this study show that since after the pronouncement of the amnesty, there has been renewed concerns over the prevailing security situation in the region. Proper reintegration of the exmilitants to live responsible life constitute serious problem to the committee. Moreover, the majority of the exmilitants are finding it difficult to shade-off their criminal tendencies. The the study reveals that, ex-militants continue to be involved in one criminal activity or another. Such acts range from extortion, arm robbery and assault as mean of sustenance, having been restricted from oil bunkering, sea piracy, kidnapping and illegal arm proliferation, among others. Once again, public peace has been threatened and thus calls to question the confidence on the good motive of the amnesty programme. Other challenges uncovered by this study include:

1. Re-occurrence of crimes: The success of the amnesty programmes is questionable due to the emergence of post amnesty crimes in the region. The study reveals that on October 8, 2009, about four (4) ex-militants, flashed their amnesty identity cards on a man in a Mercedes Benz and compelled him to drive them to Azikiwe Street, Mile 2, Diobu, Port Harcourt. Also, on October 9, 2009 another ex-militant, broke into peoples' shops along Borokiri area of Port Harcourt and made away with valuables worth thousands of naira. The same incidence occurred at No. 5, Victor Street, Old GRA, Port Harcourt. The ex-militants have been reported to be imposing compulsory levies of between N5,000 to N10,000.00 on artisans operating along major roads in Port Harcourt. The same incidences are being reported in Bayelsa, Delta, Imo, and part of Akwa Ibom State.

2. High consumptions of illicit drugs among ex-militants: The study has revealed that, the level of consumption of illicit drugs such as cannabis, Indian hemp, alcoholic beverages and cigarettes is very high among inmates. Unfortunately, the consumption of these drugs has gradually spread into the city and has found its ways into primary, secondary and tertiary institutions resulting in the increased sales and patronage. The implication of drug infested society means that in the future, so many youths will become drug addicts, school drop-out, while insanity, madness and brain retardation will be common. Such society will suffer from poor and inefficient manpower, low productivity, underdevelopment and poverty.

3. Pressure on oil companies/multinationals for illegal contracts: Presently, ex-militants still issue threat letters to multinational oil companies for illegal contracts, especially in the security sector. The contracts are meant for the militants to protect the companies from attack by other ex-militant groups. It is envisaged that this is likely to constitute another volatile avenue for confrontation by the various cult and militant groups. It is feared that these groups will continue to jeopardize the goals of the amnesty programmes.

4. Threat to local government councils and their executives: This study shows that ex-militants continue to threaten local governments and their administrators. They continually make demands both on the local council and to its officials and such demands are often confrontational. Usually, they disrupt council activities through their protest if their demands are not met within a specified period of time.

5. Intra/inter-cult differences among ex-militants: It could be recalled that, repented militants were members of different cult organizations whose membership have not been denounced after amnesty. Findings show that, each ex-militant still maintain their former cult group, attend meetings and carry out all activities that the group demand. Within the rehabilitation camp, cult groups operate freely and confrontationally with another gang groups. There is a bitter rivalry between these groups and there is likelihood that the groups may want to seek revenge for their past losses (Reuters, 2009). 
6. Activities of government officials/politicians: Findings from this study revealed that government officials and politicians are capitalizing on the federal government's amnesty programme to score cheap political points thereby working against the success of the programme.

7. Poor facilities/professional at the rehabilitation camp: The study reveals that the ex-militant rehabilitation camps lack basic rehabilitation facilities and expert personnels. The camps also lack the capacity to reintegrate repentant militant considering the fact that militants are in the state of mental and spiritual rebellion against any constituted authority. Some ex-militants required much more than financial empowerment and training but psychiatric and mental rehabilitation. In addition, infrastructures are inadequate at the centre, while the existing ones are in a state of decay. Also, there is a noticeable delay in payment of stipends to inmates who are always on the neck of camp officials since majority of these ex-militants were used to quick money and high standard of living (Adebayo, 2010). The study has also revealed that, some militants who were arrested before the pronouncement of the amnesty are still detained in police custodies. These ex-militants are unhappy that some of their colleagues have not been released despite government directive. This action is considered by ex-militants as an unfulfilled promised on the part of the government and is capable of renewing conflicts between repentant militants and the governments.

\section{Conclusion}

The findings of the study draw attention to the fact that in reality government has recognized the Niger Delta problems and has taken a bold steps towards solving them. Findings show that, for the repentant militants to surrender their arms in the spirit of amnesty, the Niger Delta militants have demonstrated their acceptance for peace and progress in the region. However, the study uncovers that, there are enormous challenges faced by the Presidential Amnesty Implementation Committee, and if the goals of the programme must be achieved for sustainable peace in the region, the following policy suggestions need to be adopted:

1. There must be a critical, inter-sectoral and comprehensive definition of the amnesty goals and the functions of the implementation committee clearly spelt out. This will make clear the components of the amnesty programme and what the committee ought to do in definite terms.

2. The committee must focus more on supportive investment.That is, critical and substantial investment must be done in areas such as manpower training, education empowerment as well as psychological and psychiatric re-orientation.

3. There must be definite steps to identify real -ex-militants. To achieve this, government must liaise with community opinion leaders, village heads, and local government representatives to obtain bio-data of all repented ex-militants. A culturally sensitive programme should be design to facilitate the process that guarantees the programmes success.

4. Rehabilitation and re-integration exercise should be decentralized and training camps be established in each of the local government areas of the region.

5. Massive infrastructural and human capital development of the region must be undertaken jointly by the state and federal governments and the oil companies operating in the area. Empowerment opportunities should be expanded to absorb trained and qualified youths from the area. Planning, implementation as well as monitoring options and principles should be evolved to guide the committee in delivering its services. It is believed that the findings and recommendations of this study will aid the policy makers to ensure that the Federal Government Amnesty Programme surely yield the desired dividend namely sustainable peace and progress in the Niger Delta Region and the Nigeria nation at large.

References

[1]. Adebayo, S. (2010). “20,192 Ex-militants Begin six months training today”, The punch, 28 June, viewed 2 April 2013.< http:/www.nigeria 70.com/239773.

[2]. Awoniyi, O. (2009). "Amnesty to militants offer Nigeria Huge Success in Niger Delta". Xinhua, 29 November, viewed 28 August 2013, < http://www.reliefweb.int/report/nigeria/amnesty.com

[3]. Ayaero, C. (2009). "What Nest After Amnesty", The Vanguard, 25 September, viewed 14 August 2013 , < http//www.vanguardngr.com

[4]. Charles, O. and Dayo, A. (2008). “Oil Has Been a Blessing and a Curse” Tell, 18 February, p.14.

[5]. Dode, R. O. (2007). Incidents of Hostage Taking and the Niger Delta Crisis in Nigeria. South South Journal of Culture and Development, Nigeria, pp. 17-21.

[6]. Ebo, A. (2008). "Small Arms Proliferation in Nigeria": A preliminary overview In Okwuchukwu I. and Fatima Kyani Mohammed (eds) Oiling violence, proliferation of small arms \& light weapons in the Niger Delta. Abuja Friedrich.

[7]. Edokpayi, M. K. (2009). Isaac Adaka Boro and Niger Delta Militancy. Word Press.

[8]. Emmanuel, K. (2005). "Proliferation of small arms and Ethnic conflict in Nigeria: Implications for National Security. St. Clements University Pubs.

[9]. Etim, T. I. and Onwuka, S. (2006). "Niger Delta Militant strike again". Legal Oil.

[10]. Ibeanu, O. (1997). Oil, conflict and security in Rural Nigeria: Issues in the Ogoni Crisis. AAPS occasional paper series, vol. 1, No. 2. pp......

[11]. Izeze, I. (1999). "Defining the Niger Delta". The Guardian, October 7, p. 24. 
[12]. Judith, A. (2009). "Understanding the Armed Groups of the Niger Delta". In Okoko K. (ed) The politics of oil, and the development of under-development in the Niger Delta. University of Port Harcourt Press.

[13]. Naangbanton, B. (2007). "Oil Producing Minorities and the Reconstruction of the Nigeria Federation: The case of the Ogoni People", Journal of common wealth and comparative studies, vol. 33, No. 1. pp. 32-41.

[14]. Nwankwo, N. and Ifeadi, C. N. (1998). "Case Studies on the Environmental Impact of Oil Production and marketing in Nigeria" University of Lagos Press.

[15]. Odile, A. (2008). Crime in the oil Business: Oil Bunkering in Nigeria. Suite 101. Comm insightful Writers informed.

[16]. Osaghae, E. (2006). "The Ogoni Uprising: Oil Politics, Minority Agitations and the future of the Nigerian State" African Affairs, vol. 94. pp. 66-70.

[17]. Reuter, G. (2009). "Nigeria to unveil Amnesty Programme for Militants”, 5 June, viewed 2 July 2010,< http:www.net. com

[18]. Strouse, T. (2009). "Will Nigeria's Amnesty Campaign have a lasting impact on the Delta insurgency? Jametown Terrorism Monitor, 2 November, viewed. 22 September.

[19]. Ukiwo, U. (2008). Nationalization Versus Indigenization of the Rentier Space: Oil and Conflicts in Nigeria: In Omeje, k. (ed) Extractive Economics and Conflict in the Global South: Multi-regional perspectives on rentier politics. Adlershot: Ashgate.

[20]. Wikipedia (2013). http://www. wikipedia, the free encyclopedia. Retrieved 2013-07-24 